\title{
The Study and Exposure of Law of Distribution Protein Substances in Uroliths
}

\author{
OA Golovanova* \\ Omsk State University, Omsk, Russia \\ *Corresponding author: OA Golovanova, Omsk State University, Omsk, Russia
}

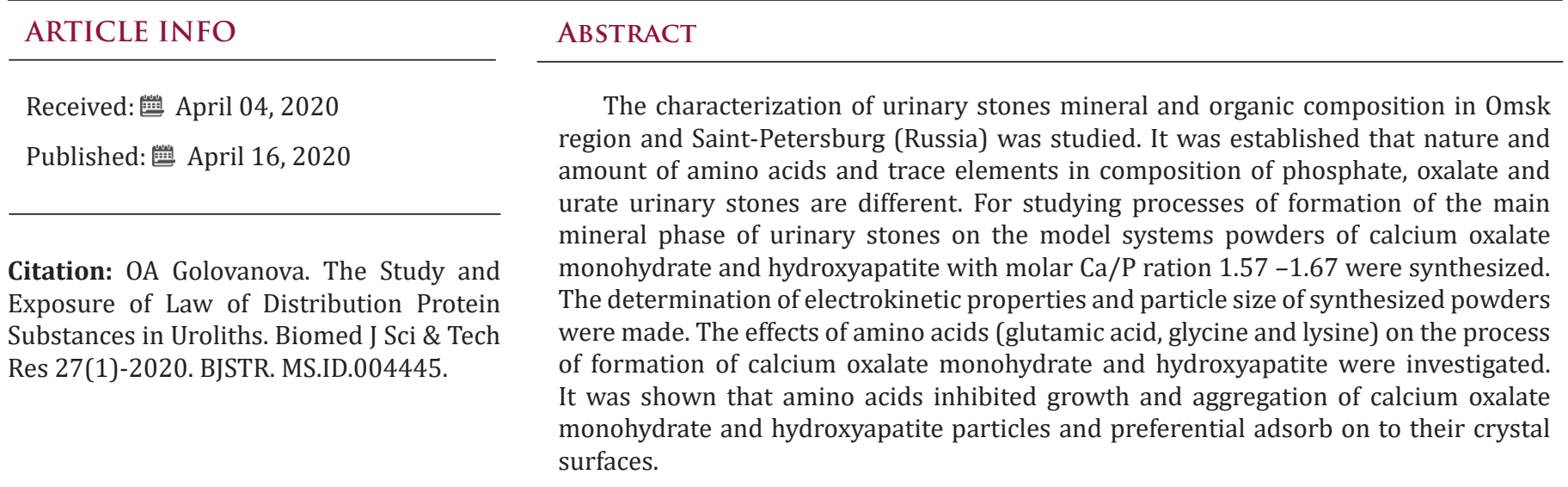

\section{Introduction}

The great importance of organic matter in many geological processes is well known. However, minerals can form not only in the bowels of the earth, but also in living organisms, including humans. The human body is a complicated system of organic and inorganic substances that are maintained in balance. However, certain factors may upset the balance, with pathological formation of biogenic minerals in human tissues and organs being a possible consequence. Biological mineralization is an important biological process in living organism. It can be a normal phenomenon such as the formation of bone and teeth or a pathological process such as the formation of renal stones (urolithiasis). Urinary stones may be regarded as an example of biomineralization that involves the formation of inorganic minerals by living organisms. Renal stone is a pathological manifestation of the phenomenon, exhibiting features typical to those of uncontrolled biomineralization.

The problem of renal stones is one of the oldest medical afflictions known to mankind. Today it is one of the most common diseases of the urinary system.

Statistics inform about the increase of the general quantity of patients with urolithiasis. Patients with urolithiasis amount to $40 \%$ among the urology profile patients. Urinary stones typically affect the most active people between 20-50 years of age. Detailed analysis of urinary calculi, including their composition, structure, ontogenetic characteristics, and modeling crystallization processes of mineral phase of urinary stones in aqueous solutions, at physiological conditions are necessary for understanding the causes and mechanisms of urolithiasis. These data permit a more effective development of the methods for treatment of this pathology and prevention of the disease or its relapses.This study was aimed to analyze the organic component and trace elements of renal calculi and its relationships with the mineral components, synthesize hydroxyapatites with different molar $\mathrm{Ca} / \mathrm{P}$ ration and calcium oxalate monohydrate (under physiological condition) and examine the specific of their cooperating with amino acids.

\section{Experimental}

\section{Composition and Structure Determination of Urinary Stones}

X-Ray Powder Diffraction: The identities of mineral crystals phases of urolithes were confirmed by X-ray analysis. The crystals were grounded thoroughly and their X-ray diffraction patterns were recorded with a DRON-3 powder autodiffractometer. BraggBrentano geometry and graphite monochromator were placed on the diffracted beam. CuK $\alpha$-radiation $(\lambda=1,54178 \AA$ ) was used. Powder spectrum was recorded at $25{ }^{\circ} \mathrm{C}$ in the range of $2 \Theta=9-$ 55. The decoding patterns were carried out by comparison of d-spacing (distances) of samples with d-spacing (distances) of pure substances with the aid of card file ASTM. 
IR-Spectroscopy: Infrared spectra of all urinary calculi were recorded as $\mathrm{KBr}$ pellets using a Specord - 75 IR spectrophotometer. Infrared spectra patterns were recorded between wavenumber 400 - $4000 \mathrm{~cm}^{-1}$. Components identification was carried out using the "Atlas of Infrared Spectra for the Analysis of Urinary Concrements" (New York, 1988).

Synchrotron X-ray Fluorescence Spectrometry: The identities of trace elements of urolithes were confirmed by synchrotron X-ray fluorescence spectrometry. The XRF work was performed at VEPP-3 with high-flux synchrotron radiation from electron-accelerating super photon ring, with radiation energy 22 $\mathrm{keV}$ (for quantitative determination: $\mathrm{Ti}, \mathrm{V}, \mathrm{Cr}, \mathrm{Mn}, \mathrm{Fe}, \mathrm{Ni}, \mathrm{Cu}, \mathrm{Zn}, \mathrm{Ga}$, As, Se, Br, Rb, Sr, Y, Zr, Nb, Mo, Pb, Th, U) and $42 \mathrm{keV}$ (for quantitative determination: Ag, Cd, In, Sn, Sb, Te, I, Cs, Ba, La , Ce). Components identification and quantitative analyses was made using method of outside standard.

The Analysis of Organic Matter of Urinary Stones: Qualitative and quantitative composition of amino acids of renal stones was determined by the Ion-Exchange Chromatography method. The samples (1.5 grams) are transferred to a hydrolysis tube and dried under vacuum. The tube was placed in a vial containing $6 \mathrm{~N} \mathrm{HCl}$ and the sample was hydrolyzed by the $\mathrm{HCl}$ vapors under vacuum. The hydrolysis was carried out for 24 hours at $110{ }^{\circ} \mathrm{C}$. After hydrolysis and filtering, the samples were dissolved in bidistilled water. The amino acids are separated on Ion-Exchange Chromatographer $\mathrm{T}$ - 339 with spectrophotometrical detector. Spectrophotometrical Benedict's methods were used to measure the total concentrations of water-soluble organic protein-containing compounds, in the urinary calculi. The choice of these methods was determined by the specificity of the objects of study. This allowed us to obtain a more correct information on their concentrations in the biogenic minerals.

\section{Model Experiments}

\section{Synthesize of Hydroxyapatites With Different Molar Ca/P Ration}

Aqueous solutions of $\mathrm{Ca}\left(\mathrm{NO}_{3}\right)_{2} \bullet 4 \mathrm{H}_{2} \mathrm{O},\left(\mathrm{NH}_{4}\right)_{2} \mathrm{HPO}_{4}$ and ammonia were used as the starting components of the system. The solutions were prepared using doubly distilled water. The counter ions $\mathrm{NH}_{4}^{+}$ and $\mathrm{NO}_{3}^{-}$were chosen because they are known to incorporated little in hydroxyapatite structure. Hydroxyapatite powders were synthesized under physiological condition of $37{ }^{\circ} \mathrm{C}$, concentration of phosphate $(0.02 \mathrm{~mol} / \mathrm{l})$ and $\mathrm{pH} 24$ hour $=7.5 \pm 0.1$. The $\mathrm{Ca} / \mathrm{P}$ ratio in the initial mixture varying from 1.67 to 1.90 . The $\mathrm{pH} 24$ hour value during precipitation in different experiments was controlled by addition of $\mathrm{NH} 4 \mathrm{OH}(1: 1)$ or $\mathrm{HNO} 3$ (1:1). The solution $\left(\mathrm{NH}_{4}\right)_{2} \mathrm{HPO}_{4}$ was added to the reaction mixture, containing $\mathrm{Ca}\left(\mathrm{NO}_{3}\right)_{2} \bullet 4 \mathrm{H}_{2} \mathrm{O}$, and ammonia .The $\mathrm{pH}$ values of the equilibrium phases were measured (after 24 hour of crystallization) and the $\mathrm{Ca}_{2}{ }^{+}$and $\mathrm{PO}_{4}{ }^{3-}$ ion contents were determined. The analytical data for the liquid phases were used to calculate the ratio $\mathrm{Ca} / \mathrm{P}$ in the solid phases. The solid phases were filtered off, washed with distilled water and dried in air at room temperature. Calcium was determined chelatonometrically with murexide; phosphorus was determined spectrophotometrically by "molybdate blue". The X-ray phase analysis was performed on a DRON-3 diffractometer using the $\mathrm{CuK} \alpha$-radiation.

\section{Synthesize of Calcium 0xalate Monohydrate}

The initial substances were aqueous solutions of $\mathrm{CaCl}_{2}$, $\left(\mathrm{NH}_{4}\right)_{2} \mathrm{C}_{2} \mathrm{O}_{4}$ and ammonia. Calcium oxalate monohydrate powders were synthesized under physiological condition of $37^{\circ} \mathrm{C}$, and $\mathrm{pH}$ $=6.5 \pm 0.1$. The interactions in the system were studied under the condition of physiological supersaturation of calcium oxalate $\gamma$ $=\mathrm{C} / \mathrm{C}_{\infty}=7$. The maintenance of $\mathrm{pH}$ value during precipitation in different experiments was controlled by addition of $\mathrm{NH}_{4} \mathrm{OH}(1: 1)$ or $\mathrm{HNO}_{3}(1: 1)$. The X-ray phase analysis was performed on a DRON-3 diffractometer using the $\mathrm{CuK} \alpha$-radiation.

\section{Determination of Electrokinetic Properties of Hydroxy- apatite Particles}

The determination of the electrokinetic properties of hydroxyapatite particles $(\mathrm{Ca} / \mathrm{P}=1,58 \pm 0,01 ; 1,65 \pm 0,01$ and $1,67 \pm 0,01$ ) was made by the electrophoresis method, using technique by Rabinovich - Fodiman $(\mathrm{E}=260 \mathrm{~V})$. This method is based on movement of a charged particle relative to the liquid it is suspended in under the influence of an applied electric field. Zeta potential of the particle was calculated by application of the Gelmgolz - Smoluchowski equation: $\xi=\frac{4 \pi \eta U}{\varepsilon H} 300^{2}$, where $\xi$ - zeta potential; $\eta$ - viscosity; $\varepsilon$ - dielectric constant; U electrophoretic rate; $\mathrm{H}$ - gradient of potential of an applied electric field.

\section{Particle Size Analyze}

The determination of the particle size analyze of synthesized powders of calcium oxalate and hydroxyapatite were made with Laser Diffraction Particle Size Analyzer SALD-2101 (Shimadzu, Japan). The Diffraction Particle Sizer is based on the principle of laser ensemble light scattering. They fall into the category of nonimaging optical systems due to the fact that sizing is accomplished without forming an image of the particle onto a detector. A single optical system covers a total particle range of $0.03 \mu \mathrm{m}$ to $1000 \mu \mathrm{m}$. Since only one optical system is needed for measurement, accurate particle distribution curves are obtained without cumbersome calculations. Forward diffracted/scattered light is sensed by a 76-element 'wing' sensor of unique design, while side and back scattered light is sensed by five other sensors. Since a total of 81 sensing elements are used, exceptionally high resolution is achieved.

\section{Statistical Analysis}

Experimental data were analyzed using the Statistica 6.0 software package.

\section{Results and Discussion}

The studies of physical and chemical properties of urinary stones are important to understand their formation. For the identification of the mineral chemical composition, some analytical techniques were applied, such as X-ray diffraction and infrared spectroscopy. We obtained 210 urinary stones from patients aged 
between 20-70 year after open surgery and shock-wave lithotripsy. The X-ray diffraction and infrared spectroscopy methods permitted to establish that $25 \%$ calculi corresponded to calcium oxalate (calcium oxalate monohydrate, calcium oxalate dehydrate), $10 \%$ to calcium phosphate (hydroxyapatite, struvite, brushite), $7 \%$ to uric acid calculi, $50 \%$ to calcium oxalate/phosphate mixed calculi and $11 \%$ to calcium oxalate/uric acid mixed calculi. Table 1 summarizes of the results obtained by the X-ray and IR- spectroscopy studies. Our results, obtained on given stones, have shown that the most part of urinary stone has polymineral composition; that is why we studied the feature of zonal structure of some stones after open surgery. The composition of the stone regions (nucleus, middle and peripheral layers) was determined by powder X-ray diffraction analysis of the material removed from selected locations of the stone.

The results obtained by the X-ray studies gave us information that in urinary stones there are consecutive zones, which contain mineral of calcium oxalate and calcium phosphate types, or calcium oxalate and uric acid types. Consecutive zones with calcium phosphate and uric acid were not found. These data reflect the specificity of urinary stones crystallization process, because of the complex nature of the stone formation condition, the chemical composition and the crystalline structure strongly vary from stone to stone and within a given stone. To determine the characteristics of the protein distribution in the calculi, we used Benedict's method to analyze an oxalate-phosphate sample with a zonal structure layer by layer. The results were interesting in that the concentrations of water-soluble proteins in seven sequential layers from the center to the periphery followed a normal distribution (Figure 1). This is a good illustration of the processes in the human body accompanying the formation of the calculus, specifically, inflammation. Cellular and humoral processes collectively called inflammation are induced, in a definite order, in the tissues into which microorganisms or other irritators have penetrated. Inflammation may be regarded as the body's protective measure. Since the changes that accompany the growth of calculi influence their structural and ontogenetic characteristics, the latter reflect the patterns of the inflammatory processes themselves. This is why the normal distribution of water-soluble proteins (products of inflammation) graphically reflects the progress of inflammation, which is an oscillatory postaggressive reaction. These oscillations are random; they emerge irregularly in response to an unusual environmental factor. The body compensates for this disturbance using various protective measures; the equilibrium is restored by gradual damping of the disturbance and subsequent reactions.

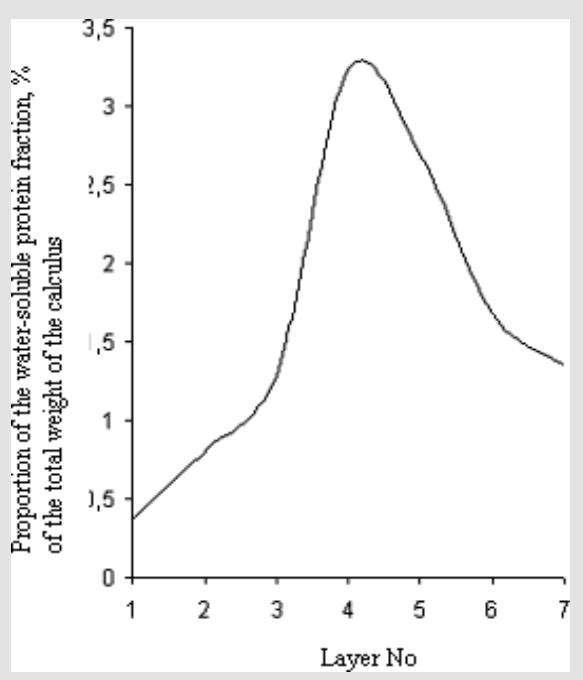

Figure 1: Layer-by-layer analysis of an oxalate--phosphate calculus by Benedict's method.

Table 1: Frequency meeting of minerals in urine stones of Omsk region and Saint-Petersburg (Russia) patients with uroliths.

\begin{tabular}{|c|c|c|}
\hline \multirow{2}{*}{ Mineral } & \multicolumn{2}{|c|}{ Frequency, $\%$} \\
\cline { 2 - 3 } & Omsk Region & \multicolumn{2}{|c|}{ Saint-Petersburg } \\
\hline Whewellite $\mathrm{CaC}_{2} \mathrm{O}_{4} \cdot \mathrm{H}_{2} \mathrm{O}$ & 40.7 & 12.3 \\
\hline Whedellite $\mathrm{CaC}_{2} \mathrm{O}_{4} \cdot 2 \mathrm{H}_{2} \mathrm{O}$ & 16.4 & 21.8 \\
\hline Struvite $\mathrm{NH}_{4} \mathrm{MgPO}_{4} \cdot 6 \mathrm{H}_{2} \mathrm{O}$ & 5.5 & 2.3 \\
\hline Hydroxyapatite $\mathrm{Ca}_{5}\left(\mathrm{PO}_{4}\right)_{3} \mathrm{OH}$ & 23.8 & 2.0 \\
\hline Vitlokit $\mathrm{Ca}_{3}\left(\mathrm{PO}_{4}\right)_{2}$ & 1.8 & 1.6 \\
\hline Brushite $\mathrm{CaHPO}_{4} \cdot 2 \mathrm{H}_{2} \mathrm{O}$ & 0.0 & 0.0 \\
\hline Uric acid hydrate $\mathrm{C}_{5} \mathrm{H}_{4} \mathrm{~N}_{4} \mathrm{O}_{3} \cdot 2 \mathrm{H}_{2} \mathrm{O}$ & 0.9 & 2 \\
\hline
\end{tabular}




\begin{tabular}{|c|l|c|}
\hline Uric acid $\mathrm{C}_{5} \mathrm{H}_{4} \mathrm{~N}_{4} \mathrm{O}_{3}$ & 9.3 & 9.0 \\
\hline Ammonium hydrogen urate & 0.3 & 0.0 \\
\hline Quartz $\mathrm{SiO}_{2}$ & 0.6 & 0.0 \\
\hline
\end{tabular}

Using the method of Ion-Exchange Chromatographer with spectrophotometrical detector we determined 10 - 14 amino acids (Table 2) in the composition of most popular types of urinary stones. Our results, obtained on given stones have shown that the mass share (wt\%) of amino acids varies from 0.610 to $2.228 \%$ depending on the stone type. We can point out that qualitative and quantitative compositions of amino acids in different stone types varies. This dependence can be illustrated by line: uric acid calculi (wt $\%=2.228 \%, 11$ amino acids) $>$ calcium oxalate/uric acid mixed calculi (wt $\%=2.024-2.109 \%, 11$ amino acids) > calcium phosphate calculi ( $w \mathrm{t} \%=1.755-2.187 \%, 14$ amino acids) > calcium oxalate/ phosphate mixed calculi (wt\%=0.918- 0.996\%, 10 amino acids) $>$ calcium oxalate calculi (wt $\%=0.610-0.701 \%, 10$ amino acids). Threonine, serine, glycin, alanine, valine, methionine, glutamine, phenylalanine and lysine were found in nearly all the calculi, whereas tryptophan, isoleucine, leucine and proline occurred randomly. It was established, that percentage of glutamine and lysine are the major components of organic matter in the all prominent classes of renal stones. The results of qualitative and quantitative determination of compositions of amino acids in renal stones of the different mineral types are presented in Table 2 .

Table 2: The results of qualitative and quantitative determination of compositions of amino acids in renal stones of the different mineral types.

\begin{tabular}{|c|c|c|c|c|c|}
\hline \multirow[t]{2}{*}{ Amino Acid } & \multicolumn{5}{|c|}{ Contents of Amino Acid, \% wt. } \\
\hline & $\begin{array}{l}\text { calcium oxalate } \\
\text { calculi }\end{array}$ & $\begin{array}{l}\text { calcium phosphate } \\
\text { calculi }\end{array}$ & uric acid calculi & $\begin{array}{l}\text { calcium oxalate/ } \\
\text { phosphate mixed } \\
\text { calculi }\end{array}$ & $\begin{array}{c}\text { calcium oxalate/ } \\
\text { uric acid mixed } \\
\text { calculi }\end{array}$ \\
\hline $\begin{array}{c}\text { Tryptophan } \\
{\left[\mathrm{HNC}_{7} \mathrm{H}_{5} \mathrm{CH}_{2}\left(\mathrm{NH}_{2}\right) \mathrm{CHCOOH}\right]}\end{array}$ & not detected & $0.021-0.103$ & not detected & not detected & not detected \\
\hline $\begin{array}{c}\text { Isoleucine } \\
{\left[\mathrm{CH}_{3} \mathrm{CH}_{2} \mathrm{CH}\left(\mathrm{CH}_{3}\right) \mathrm{CH}\left(\mathrm{NH}_{2}\right) \mathrm{COOH}\right]}\end{array}$ & not detected & $0.000-0.054$ & not detected & not detected & not detected \\
\hline $\begin{array}{c}\text { Threonine } \\
{\left[\mathrm{CH}_{3} \mathrm{CH}(\mathrm{OH}) \mathrm{CH}\left(\mathrm{NH}_{2}\right) \mathrm{COOH}\right]}\end{array}$ & $0.037-0.52$ & $0.14-0.126$ & 0.177 & $0.069-0.073$ & $0.156-0.159$ \\
\hline Serine $\left[\mathrm{HOCH}_{2} \mathrm{CH}\left(\mathrm{NH}_{2}\right) \mathrm{COOH}\right]$ & $0.055-0.066$ & $0.105-0.11$ & 0.127 & 0.079 & $0.113-0.123$ \\
\hline Glycin $\left[\mathrm{H}_{2} \mathrm{NCH}_{2} \mathrm{COOH}\right]$ & $0.069-0.078$ & $0.112-0.115$ & 0.132 & $0.087-0.091$ & $0.125-0.13$ \\
\hline $\begin{array}{c}\text { Alanine } \\
{\left[\mathrm{CH}_{3} \mathrm{CH}\left(\mathrm{NH}_{2}\right) \mathrm{COOH}\right]}\end{array}$ & $0.065-0.077$ & $0.148-0.159$ & 0.186 & 0.097 & $0.173-0.177$ \\
\hline $\begin{array}{c}\text { Valine } \\
{\left[\left(\mathrm{CH}_{3}\right)_{2} \mathrm{CHCH}\left(\mathrm{NH}_{2}\right) \mathrm{COOH}\right]}\end{array}$ & $0.046-0.058$ & $0.122-0.132$ & 0.156 & $0.075-0.076$ & $0.144-0.148$ \\
\hline $\begin{array}{c}\text { Methionine } \\
{\left[\mathrm{CH}_{3} \mathrm{SCH}_{2} \mathrm{CH}_{2} \mathrm{CH}\left(\mathrm{NH}_{2}\right) \mathrm{COOH}\right]}\end{array}$ & $0.0002-0.0009$ & $0.045-0.051$ & 0.064 & 0.018 & $0.057-0.058$ \\
\hline $\begin{array}{c}\text { Leucine } \\
{\left[\left(\mathrm{CH}_{3}\right)^{2} \mathrm{CHCH}_{2} \mathrm{CH}\left(\mathrm{NH}_{2}\right) \mathrm{COOH}\right]}\end{array}$ & not detected & $0.021-0.148$ & not detected & not detected & not detected \\
\hline $\begin{array}{c}\text { Glutamine } \\
{\left[\mathrm{HOOCCH}\left(\mathrm{NH}_{2}\right) \mathrm{CH}_{2} \mathrm{CH}_{2} \mathrm{C}(\mathrm{O}) \mathrm{NH}_{2}\right]}\end{array}$ & $0.158-0.211$ & $0.43-0.475$ & 0.575 & $0.262-0.268$ & $0.523-0.533$ \\
\hline $\begin{array}{c}\text { Proline } \\
{\left[\mathrm{HNC}_{4} \mathrm{H}_{7} \mathrm{COOH}\right]}\end{array}$ & not detected & $0.144-0.191$ & 0.267 & not detected & $0.221-0.233$ \\
\hline $\begin{array}{c}\text { Phenylalanine } \\
{\left[\mathrm{PhCH}_{2} \mathrm{CH}\left(\mathrm{NH}_{2}\right) \mathrm{COOH}\right]}\end{array}$ & $0.02-0.032$ & $0.096-0.11$ & 0.135 & $0.047-0.049$ & $0.121-0.123$ \\
\hline $\begin{array}{c}\text { Lysine } \\
{\left[\mathrm{H}_{2} \mathrm{~N}\left(\mathrm{CH}_{2}\right)_{4} \mathrm{CH}\left(\mathrm{NH}_{2}\right) \mathrm{COOH}\right]}\end{array}$ & $0.068-0.104$ & $0.284-0.316$ & 0.389 & $0.151-0.155$ & $0.352-0.359$ \\
\hline $\begin{array}{c}\text { Arginine } \\
{\left[\mathrm{HN}=\mathrm{C}\left(\mathrm{NH}_{2}\right) \mathrm{NH}\left(\mathrm{CH}_{2}\right)_{3} \mathrm{CH}\left(\mathrm{NH}_{2}\right) \mathrm{COOH}\right]}\end{array}$ & 0.014-0.09 & $0.082-0.101$ & 0.02 & $0.023-0.106$ & $0.039-0.066$ \\
\hline
\end{tabular}

The experimental data were treated using cluster analyses and analysis of variance (ANOVA), which yielded the following results:

1. The cluster analysis using the K-mean method resulted in three distinct clusters accounted for urate, phosphate and oxalate calculi, respectively. The experimental data of amino acids mean concentration in each cluster are presented on Figure 2.
2. The combined results of cluster analysis and ANOVA confirmed that the effect of mineral composition on the amount and quantitative of organic (amino acids - containing) compounds was significant. Therefore, the typology obtained by cluster analysis was statistically significant. 


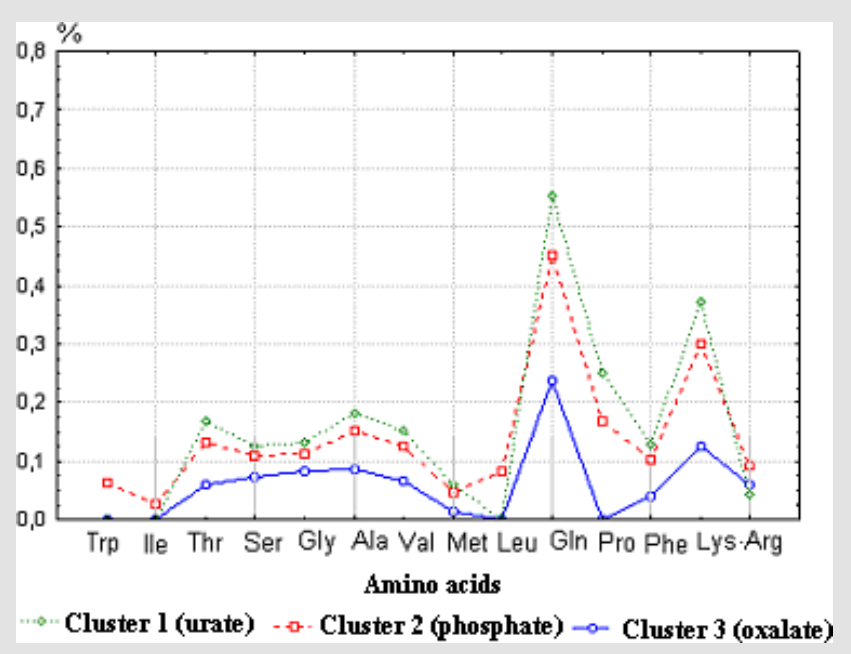

Figure 2: Mean concentration of amino acids in different cluster of urinary stones.

These results allow us to assume that qualitative and quantitative amino acids composition of urinary stones is connected with their mineral structure and therefore, urinary amino acids and proteins can be the agents which may affect the formation of urinary stones by virtue of their effects on mineral phase (calcium oxalate, calcium phosphates and etc.) crystallization R. Azoury, et al. [1-4].

Although most mechanisms concerning the behaviour of trace elements in biological systems are far from being understood, many researchers are convinced that trace elements play a major role in causing disease such as urolithiasis T. Ozgurtas [5]. The quantitative determination of trace elements in calculi is essential for the understanding of their aetiology. Analysis of elements in the calculi was carried out by synchrotron X-ray fluorescence spectrometry. Presence of 34 different trace elements was observed in these samples. The result of cluster analysis indicate that calculi with different mineral composition (phosphate, oxalate and urate) vary in containing of major $\mathrm{Ca}, \mathrm{P}, \mathrm{Mg}, \mathrm{Na}, \mathrm{K}, \mathrm{S}, \mathrm{F}$ (31 - $0.4 \mathrm{wt} . \%$ ) and trace elements $\mathrm{Sr}, \mathrm{Zn}, \mathrm{Ba}, \mathrm{Cu}, \mathrm{Br}, \mathrm{Pb}, \mathrm{Sb}, \mathrm{Zr}, \mathrm{Rb}(0.05-0.0005$ wt.\%). It was established, that calculi containing higher amounts of calcium phasphate show the presence of high concentrations of trace metals ( $\mathrm{Sr}, \mathrm{Cd}, \mathrm{Zr}$, Sb, I, Ba, Si, F, Zn, Rb). This may be attributed to the greater ability of metal ions partially replace calcium ion in crystal structure of apatites. Further research of this work was needed to establish correlation between trace metals and amino acids in the renal calculi. In this connection it is interesting to conceder that there are some statistically significant correlations between total amount of amino acids in the renal calculi and iodine $(r=0,96)$, selenium $(r=0.75)$; glycin and nickel $(r=0.60)$; tryptophan, isoleucine, leucine and strontium $(r=0.80)$. This may be ascribed to the greater complexing ability of organic species towards metal ions.

Summarizing it up we can assume, that crystallization processes occurring during the formation of stones perhaps are influenced by urinary trace element, amino acids and proteins. Detail analyses of monomineral calcium oxalate stones by the methods of electron microscopy and microprobe X-ray fluorescence spectrometry determined, that organic and inorganic fractions are arranged in concentric layer around a common nucleus. One interesting feature of such stones is that that their center usually consist organic substances and hydroxyapatite crystals (Table 3, Figure 3). Therefore some authors began to emphasize the special role of organic matter or specific complex of organic matter with mineral phase (hydroxyapatite) in the formation and growth of renal calculi. Hydroxyapatite is the main inorganic component of calcium phosphate urinary stones. Some authors come to conclusion that hydroxyapatite can play important role in formation of calcium oxalate and phosphate uroliths EL Prien, et al. [6-8]. According to this hypothesis a molecules of organic matter covering the calcium hydroxyapatite precipitate bind or trap calcium and, in this way, cause a localized high supersaturation with calcium oxalate. Thus the subsequent nucleation may be promoted and it takes place in the organic gel layer surrounding the calcium phosphate.

Table 3: The chemical composition of the strata of the urinary stone in weight $\%$.

\begin{tabular}{|c|c|c|c|c|c|c|c|c|c|}
\hline Sample & $\mathbf{C a}$ & $\mathbf{P}$ & $\mathbf{S}$ & $\mathbf{M g}$ & $\mathbf{C l}$ & $\mathbf{N a}$ & $\mathbf{K}$ & $\mathbf{Z n}$ & $\mathbf{C a} / \mathbf{P}$ \\
\hline 1 & 58.19 & 36.43 & 0.79 & 0.52 & 0.07 & 2.99 & 0.46 & - & 1.60 \\
\hline 2 & 58.01 & 36.68 & 0.78 & 0.73 & 0.14 & 2.85 & 0.32 & - & 1.58 \\
\hline 3 & 57.04 & 37.13 & 0.63 & 0.63 & 0.29 & 3.12 & 0.38 & 0.28 & 1.54 \\
\hline
\end{tabular}




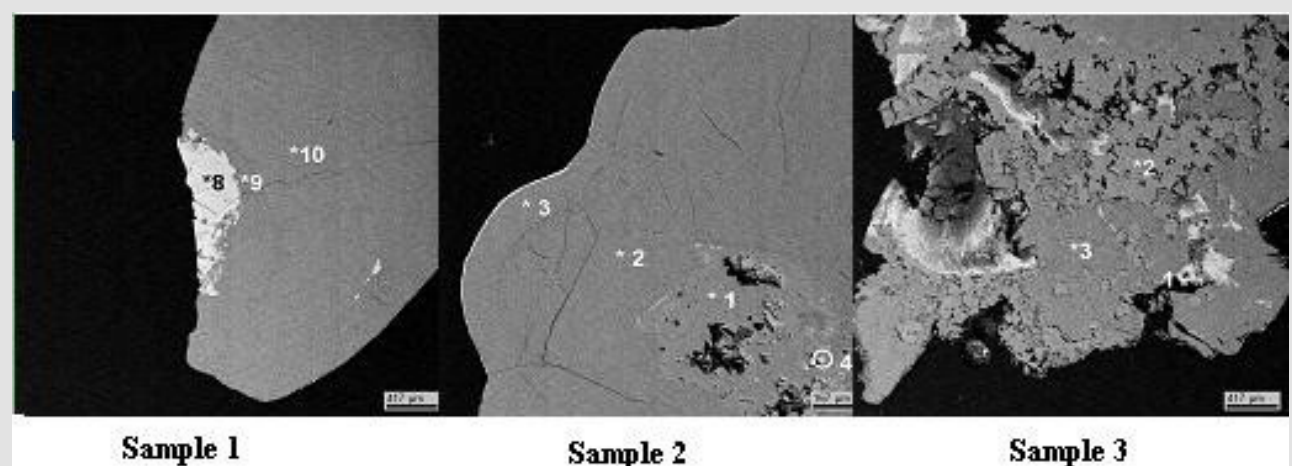

Figure 3: Electronic microscopic photos of oxalate urinary stones (white seeds - hydroxyapatite).

Table 4: Initial concentrations and the composition of solid phases in the system $\mathrm{Ca}\left(\mathrm{NO}_{3}\right)_{2}-\left(\mathrm{NH}_{4}\right)_{2} \mathrm{HPO}_{4}-\mathrm{NH}_{4} \mathrm{OH}-\mathrm{H}_{2} \mathrm{O}(\mathrm{t}=37,0 \pm$ $\left.0,5^{\circ} \mathrm{C}, \mathrm{pH}_{24 \mathrm{~h}}=7,5 \pm 0.1\right)$.

\begin{tabular}{|c|c|c|c|c|}
\hline \multirow[b]{2}{*}{ № } & \multicolumn{3}{|c|}{ Initial Solution } & \multirow{2}{*}{$\begin{array}{l}\text { Solid Phases } \\
\text { (24hour) Ca/P }\end{array}$} \\
\hline & $\mathrm{Ca}^{2+} / \mathrm{PO}^{3-4}$ & $\begin{array}{c}\text { Concentrations } \\
\mathrm{PO}_{4}{ }^{3-}, \mathrm{mmol} / \mathrm{l}\end{array}$ & $\begin{array}{c}\text { Concentrations } \\
\mathrm{Ca}^{2+}, \mathrm{mmol} / \mathrm{l}\end{array}$ & \\
\hline 1 & 1,67 & 20.00 & 33.40 & $1,58 \pm 0,01$ \\
\hline 2 & 1,75 & 20.00 & 35.00 & $1,63 \pm 0,01$ \\
\hline 3 & 1,80 & 20.00 & 36.00 & $1,65 \pm 0,01$ \\
\hline 4 & 1,90 & 20.00 & 38.00 & $1,67 \pm 0,01$ \\
\hline
\end{tabular}

Apatites, which comprise the mineral phase of biominerals, differ from pure hydroxyapatite in stoichiometry, composition and crystallinity, and other physical and mechanical properties SV Dorozhkin [9]. It was established, that urolith's apatites are Cadeficit. Therefore, synthesize hydroxyapatites with different molar $\mathrm{Ca} / \mathrm{P}$ ration and determination their properties can be necessary for understanding the causes and mechanisms of urolithiasis. The experimental data on the interaction in the system $\mathrm{Ca}\left(\mathrm{NO}_{3}\right)_{2}$ - $\left(\mathrm{NH}_{4}\right)_{2} \mathrm{HPO}_{4}-\mathrm{NH}_{4} \mathrm{OH}-\mathrm{H}_{2} \mathrm{O}\left(\mathrm{t}=37,0 \pm 0,5{ }^{\circ} \mathrm{C}, \mathrm{pH}=7,5 \pm 0.1\right)$ are presented in Table 4 . The identities of mineral crystals phases of solids were confirmed by X-ray analysis. After 24 hour of crystallization the solid phases with molar $\mathrm{Ca} / \mathrm{P}$ ration $1.57-1.67$ showed a distinct X- ray diffraction pattern, which contained all of the basic reflections of hydroxyapatite. The lines of tricalcium phosphate were absent. The magnitude of the zeta potential and surface charge of the particles gives an indication of the potential stability of the colloidal system and determines the affinity solid phase for amino acids. Zeta potential of the microparticles of hydroxyapatite with molar $\mathrm{Ca} / \mathrm{P}$ ration $1,58 \pm 0,01 ; 1,65 \pm 0,01$ and $1,67 \pm 0,01$ by electrophoretic technique (Rabinovich - Fodiman) was measured. The solution employed for the zeta-potential measurement was with $\mathrm{pH}=6.45 \pm 0.05$ and $\mathrm{I}=0.3 \mathrm{M}$. It was established, that Ca-deficient hydroxyapatite particles $(\mathrm{Ca} / \mathrm{P}=$ $1,58 \pm 0,01 ; 1,65 \pm 0,01)$ are negatively charged $(\xi=-28 \mathrm{mV} ;-8 \mathrm{mV})$, but solid phase with molar $\mathrm{Ca} / \mathrm{P}$ ration $1,67 \pm 0,01$ (stoichiometric) has positive surface $(\xi=+7 \mathrm{mV})[10,11]$.

The next aim of this work was to assess the binding of individual amino acids to the some calcium minerals found in human renal stones (calcium oxalate monohydrate and hydroxyapatite) over the physiological urinary $\mathrm{pH}$ and temperature. The amino acids studied were the $\mathrm{L}$ - forms of glutamic acid, glycine and lysine, which are the major components of organic matter of urinary stones and urine. The determination of the particle size of synthesized powders of calcium oxalate monohydrate and hydroxyapatite $(\mathrm{Ca} / \mathrm{P}=1,58 \pm 0,01$; $1,67 \pm 0,01)$ were made with Laser Diffraction Particle Size Analyzer SALD-2101 (Shimadzu), the concentration of amino acids was 0.004 mol/l (experiments with hydroxyapatite); 10-2 mol/l and 10-5 $\mathrm{mol} / \mathrm{l}$ (experiments with calcium oxalate monohydrate). Crystal size volume distribution graphs of the steady state precipitates obtained in experiments are presented in Figures 4-7. It can be seen that nearly all phases have bimodal crystal size distribution. After 24 hour, mean diameter of the crystals hydroxyapatite $(\mathrm{Ca} / \mathrm{P}$ $=1,58 \pm 0,01$ ) deposited in the presence of glycine, glutamic acid and lysine were $16.9 \mu \mathrm{m}, 14.6 \mu \mathrm{m}$ and $12.3 \mu \mathrm{m}$, in comparison with the control value of $17.3 \mu \mathrm{m}$ (solution without amino acids). This represent corresponding decreases in particle size, relative to the control, of $2.3 \%$ ( $p=0.95$, statistically nonsignificant), $15.6 \%(p=0.95$, statistically significant $)$, and $28.9 \%(p=0.95$, statistically significant), respectively. The determination of zetapotential shown, that glycine and lysine overcharged the surface of hydroxyapatite $(\mathrm{Ca} / \mathrm{P}=1,58 \pm 0,01)$ and adsorption increase as the charge on the adsorbing species become more positive. It was established, that for hydroxyapatite $(\mathrm{Ca} / \mathrm{P}=1,67 \pm 0,01)$ the greatest decreasing of particle size observed in the presence glutamic acid $(25,6 \%(p=0.95$, statistically significant $)$, which also overcharged the surface of crystals (Figures $4 \& 5$ ). 


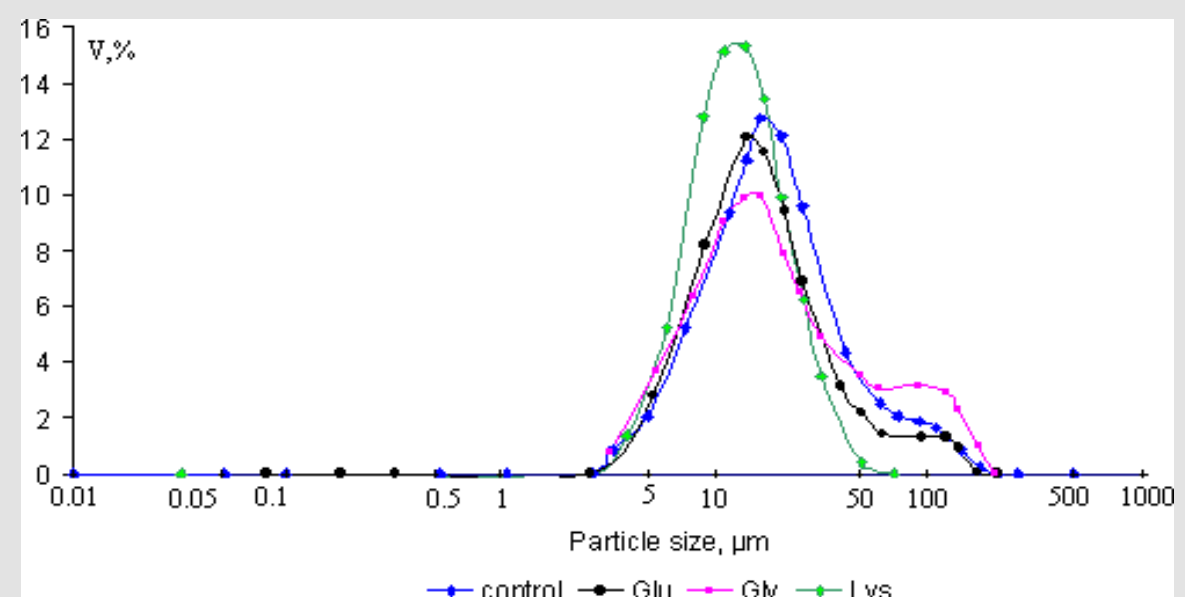

Figure 4: Crystal size volume distribution of the steady state precipitates of hydroxyapatite $(\mathrm{Ca} / \mathrm{P}=1,58 \pm 0,01)$ obtained in experiments with concentration of amino acids $0.004 \mathrm{~mol} / 1$.

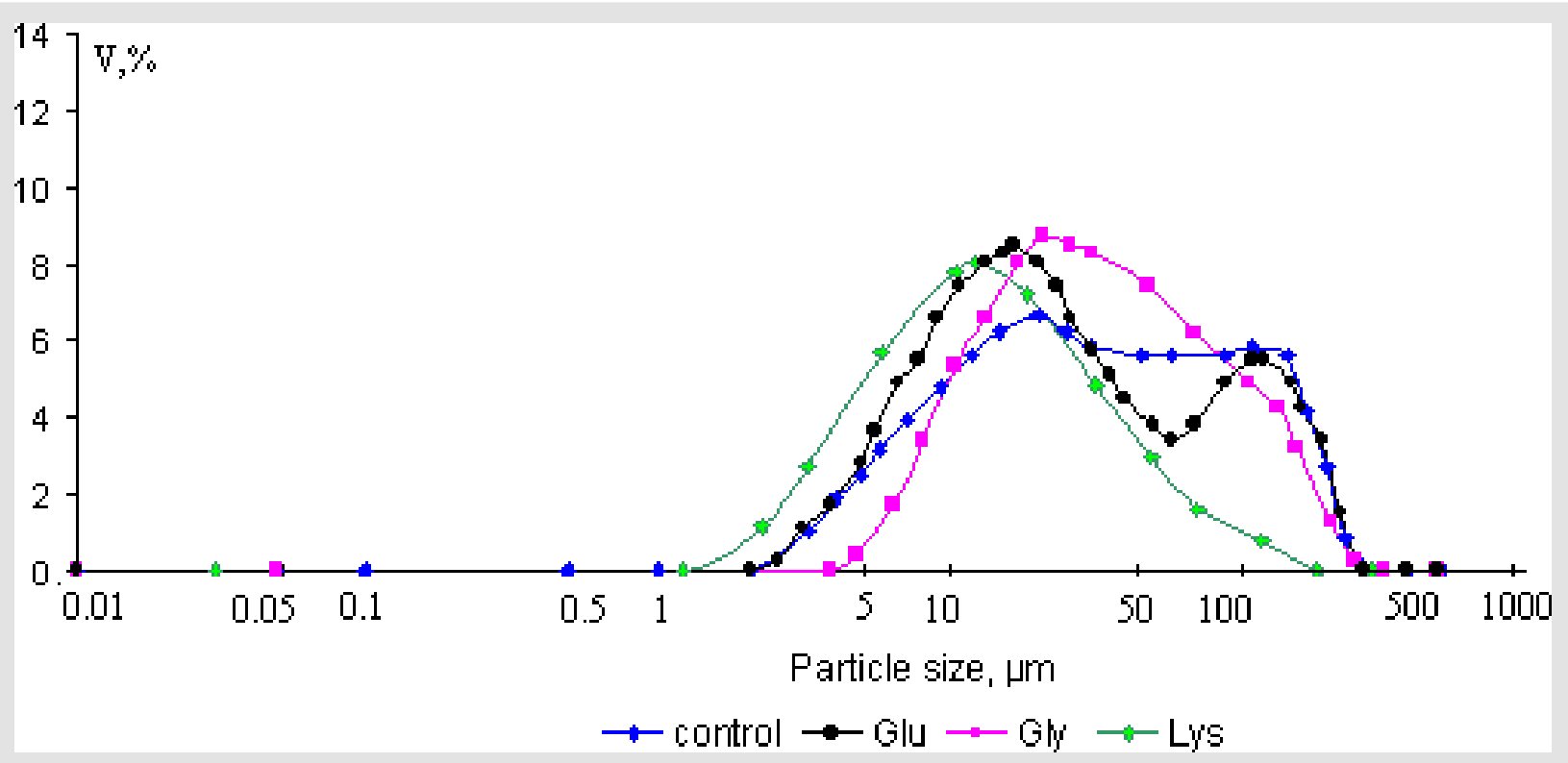

Figure 5: Crystal size volume distribution of the steady state precipitates of hydroxyapatite $(\mathrm{Ca} / \mathrm{P}=1,67 \pm 0,01)$ obtained in experiments with concentration of amino acids $0.004 \mathrm{~mol} / 1$.

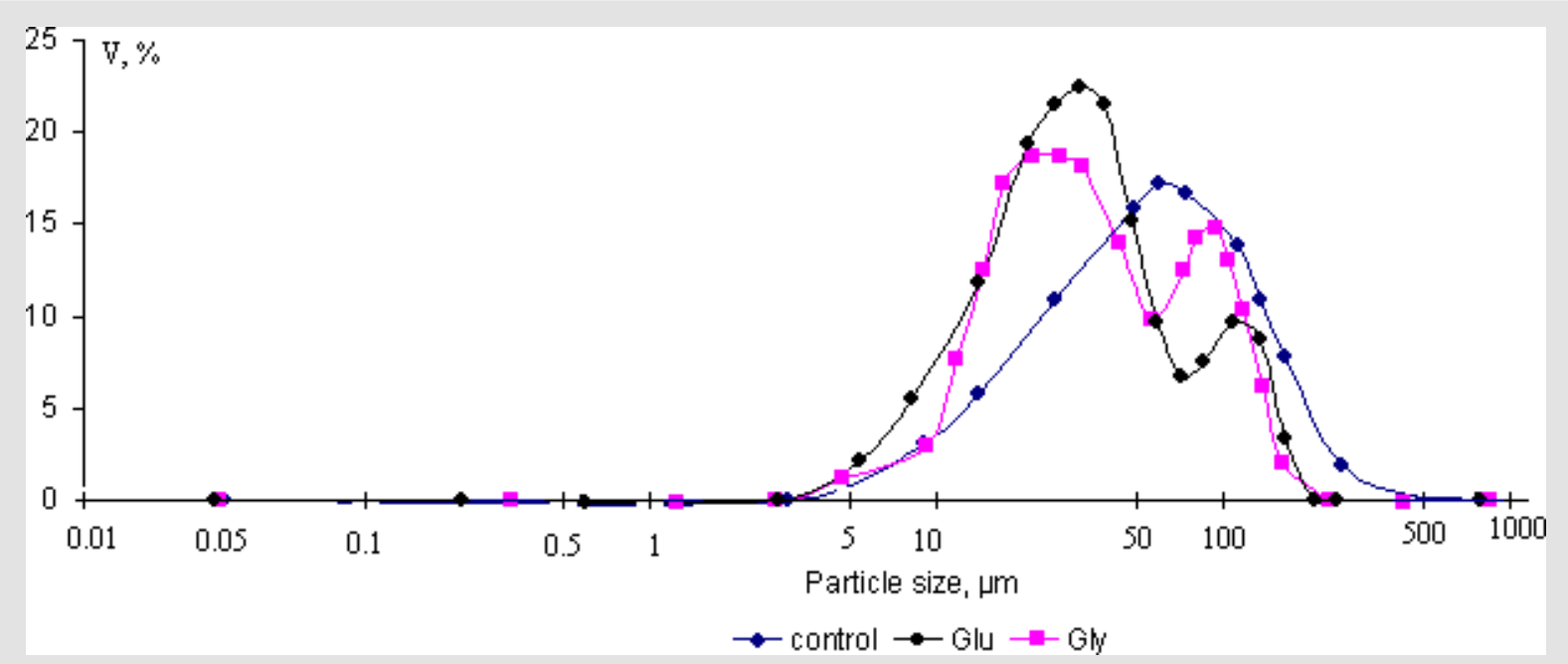

Figure 6: Crystal size volume distribution of the steady state precipitates of calcium oxalate monohydrate obtained in experiments with concentration of amino acids $10-5 \mathrm{~mol} / 1$. 


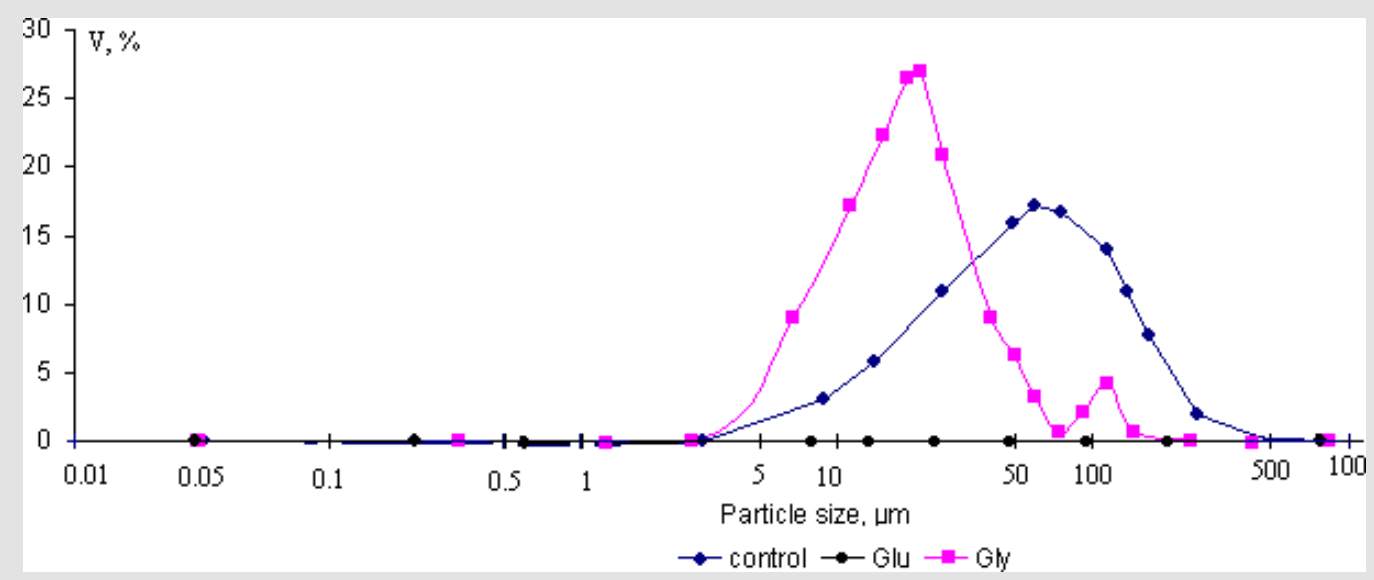

Figure 7: Crystal size volume distribution of the steady state precipitates of calcium oxalate monohydrate obtained in experiments with concentration of amino acids $10-2 \mathrm{~mol} / \mathrm{l}$.

The average size of the synthesized calcium oxalate monohydrate particles was $53.3 \mu \mathrm{m}$. The decreasing of particle size observed in the presence of glycine with concentration $\mathrm{C}=10-5$ $\mathrm{mol} / \mathrm{l}$ and 10-2 mol/l and glutamic acid ( $\mathrm{C}=10-5 \mathrm{~mol} / \mathrm{l}$ ) come to $46.3 \%, 67.9 \%$ and $43.9 \%$ ( $p=0.95$, statistically significant), respectively. In solution with concentration of glutamic acid 10-2 $\mathrm{mol} / \mathrm{l}$ any particles was not detected ( $<<0.03 \mu \mathrm{m}$ ) (Figures $6 \& 7$ ). Based on the obtained data it was established that amino acids play important role in the processes of crystallization of calcium oxalate monohydrate and hydroxyapatite. The inhibitory effect of amino acids on the processes growth and aggregation of crystals has been generally viewed as resulting from competition between amino acids and phosphate or oxalate for calcium ion in solution and their preferential adsorption on to crystal surfaces.

\section{Conclusion}

The characterization of urinary stones composition in Omsk region and Saint-Petersburg (Russia) was studied by the methods of X-ray diffraction, infrared spectroscopy, synchrotron X- ray fluorescence spectrometry, spectrophotometrical Benedict's and Ion-Exchange Chromatographer. It was established that nature and amount of amino acids and trace elements in composition of phosphate, oxalate and urate urinary stones are different. In this connection some statistically significant correlations between abundance of trace metals and amino acids in the renal calculi was specified. For studying processes of formation of the main mineral phase of urinary stones on the model systems powders of calcium oxalate monohydrate and hydroxyapatite with molar $\mathrm{Ca} / \mathrm{P}$ ration $1.57-1.67$ were synthesized. The determination of electrokinetic properties of hydroxyapatites shown that the Ca-deficient hydroxyapatites particles are negatively charged in contrast to the positive surface of stoichiometric hydroxyapatites particles.

The effects of amino acids (glutamic acid, glycine and lysine) on the process of formation of calcium oxalate monohydrate and hydroxyapatite were investigated, using method of electrophoresis and laser diffraction particle size analyzer SALD-2101 (Shimadzu). It was shown that amino acids inhibited growth and aggregation of calcium oxalate monohydrate and hydroxyapatite particles and preferential adsorb on to their crystal surfaces. These results allow us to assume that special complex of organic matter (amino acids - containing) with Ca-deficient hydroxyapatite particles can play important role in processes of formation oxalate and phosphate urinary stones especially at the initial stage. It can explain wide prevalence among urinary stones of samples oxalate and phosphate types. Information obtained from this study may be quite helpful for understanding causes and mechanism of formation any mineral types of urinary stones.

\section{References}

1. Azoury R, Garti N, Sarig S (1986) The amino acid factor in stone formers and normal urines. Urol Res 14(6): 295-298.

2. Fleming DE, Bronswijk W van, Ryall RL (2001) A comparative study of the adsorption of amino acids on to calcium minerals found in renal calculi. Clinical Science 101(2): 159-168.

3. Koutsopoulos S, Dalas E (2000) Inhibition of hydroxyapatite formation in aqueous solutions by hydrophobic side groups. Longmuir 16: 67396744.

4. Grases F, March JG, Bibiloni F, Amat E (1988) The crystallization of calcium oxalate in the presence of aminoacids. Journal of Crystal Growth 87(2-3): 299-304.

5. Ozgurtas T, Yakut G, Gulec M, Serdar M, Kutluay T (2004) Role of urinary zinc and copper on calcium oxalate stone formation. Urol Int 72(3): 233236.

6. Prien EL, Prien EL Jr (1968) Composition and structure of urinary stone. Am J Med 45(5): 654-672.

7. Elliot JS (1973) Structure and composition of urinary calculi. J Urol 109(1): 82-83.

8. Modlin M (1967) The aetiology of renal stones: A new concept arising from studies in a stone-free population. Ann R Coll Surg Engl (Lond,) 40(3): 155-178.

9. Dorozhkin SV, Epple M (2002) Biological and Medical Significance of Calcium Phosphates. Angew Chem Int Ed 41(17): 3130-3146.

10. Shubert G, Chunovskaya MV, Brin G, Tynaliev MT, Popovkin NN, et al. (1990) Feature of chemical and structure composition of renal stones of residents of Moscow. Berlin and Kirghizia Urology and nephrology 5: 49-54.

11. Golovanova OA, Yelnikov VY, Frank Kamenetskaya OV, Achkasova EY (2005) Comparative analysis of mineral composition of renal stones of Saint-Petersburg residents and other regions. Mineralogy of technogenesis - IMin UrO RAS Miass. 
ISSN: 2574-1241

DOI: 10.26717/BJSTR.2020.27.004445

OA Golovanova. Biomed J Sci \& Tech Res

(c) (P) This work is licensed under Creative

Submission Link: https://biomedres.us/submit-manuscript.php

$\begin{array}{ll}\text { BIOMEDICAL } & \text { Assets of Publishing with us } \\ \text { RESEARCHES } & \text { - Global archiving of articles } \\ \text { - Immediate, unrestricted online access } \\ \text { - Rigorous Peer Review Process } \\ \text { https://biomedres.us/ }\end{array}$

